\title{
NUMERICAL MODELS FOR THE EVALUATION OF NATURAL VIBRATION FREQUENCIES OF THERMO-MODERNIZED BUILDING WALLS
}

\author{
K. KUŹNIAR ${ }^{1}$, M. ZAJĄC ${ }^{2}$
}

\begin{abstract}
As a result of the necessity to improve energy properties of prefabricated buildings, their thermo-modernizations are performed. In the paper various approaches to the modelling of prefabricated load bearing walls before and after thermo-modernization are presented. Simple one layer models with extra mass from ceilings and equivalent stiffness as well as multilayer ones are taken into consideration using the finite element method software. Values of the natural frequencies of the wall horizontal vibrations calculated using the various models, are compared. It was proved that even the very simple model with equivalent stiffness allows to compute natural vibration frequencies of wall with acceptable accuracy for engineering practice.
\end{abstract}

Keywords: numerical models, thermo-modernized walls, natural vibration frequencies, finite element method

\footnotetext{
${ }^{1}$ Prof., DSc., PhD., Eng., Institute of Technology, Pedagogical University of Cracow, ul. Podchorążych 2, 30-084 Cracow, Poland, e-mail: kkuzniar@up.krakow.pl

${ }^{2}$ PhD., Eng., Institute of Technology, Pedagogical University of Cracow, ul. Podchorążych 2, 30-084 Cracow, Poland, e-mail: mjzajac@up.krakow.pl
} 


\section{INTRODUCTION}

The group of typical prefabricated buildings (an example is shown in Fig. 1) is very huge among apartment buildings in Poland. They were built in 50's, 60's and 70's of 20th century. Nowadays, because of the new environmental regulations as well as the expectations of current lodgers, they are modernized. Mainly, modernization deals with heat insulation.

This type of modernization of prefabricated buildings has been widely used, for example, in France already since the seventies of the twentieth century [3]. In East Germany after the fall of the Berlin Wall thermo-modernization of large prefabricated housing estates allowed not only to improve heat isolation of buildings but also to get the modern look of them [9]. In Poland thanks to EU funds a lot of prefabricated buildings (apartment and public utility buildings) have been also modernized.

This kind of modification brings additional mass to the building, changes its stiffness and, as the result, the dynamic properties of the structure could be changed. Changes in the natural frequencies of vibrations are the most important among them - calculations of these values are necessary especially in the case of objects subjected to paraseismic or seismic excitations [11].

The most popular of buildings' heat isolation technology makes walls thicker by adding the extra layers of styrofoam, rock or mineral wool, reinforced mortar, glass fibre textile mesh. For the analysis of such walls many different numerical models of multi-layer structures as the sandwich panels have been proposed $[1,6,18]$.

A great number of published papers deal with the examinations of the influence of the solutions of concrete sandwich walls (which combine structural and thermal efficiencies) on the reduction of the energy consuming, cf. e.g. $[4,12,14,15,16]$. Whereas the subject of dynamic analysis of the buildings with thermo-isolated bearing walls is poorly represented in the literature.

In the paper values of natural vibration frequencies of prefabricated walls before and after thermomodernization are computed using various approaches to the wall modelling 


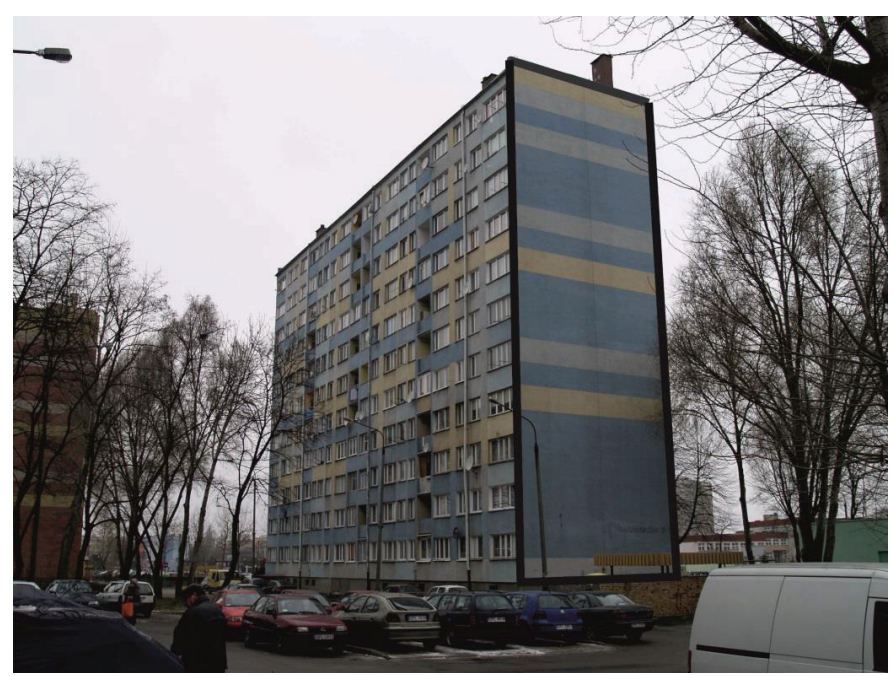

Fig. 1. Typical high-rise prefabricated apartment building

\section{ANALYSED WALL}

Typical high reinforced concrete load bearing wall of WWP prefabricated system [7] (marked in Fig. 1) was considered $-10.8 \mathrm{~m}$ width and $29.7 \mathrm{~m}$ (11 storeys $\mathrm{x} 2.7 \mathrm{~m}$ ) height. Each of the prefabricated wall panels have 3 layers: load bearing, thermal insulation and elevation. Extra thermo-modernization part consists of reinforced mortar, styrofoam and glass fibre textile mesh [10]. Wall's layers as well as their thickness are presented in Fig. 2 and Table 1.

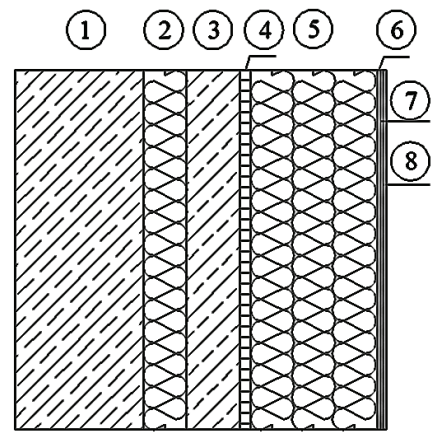

Fig. 2. Layers of the analysed wall 
Table 1. Wall layers and their thickness

\begin{tabular}{|c|c|c|}
\hline Layer & Material & Thickness $[\mathbf{c m}]$ \\
\hline 1 & reinforced concrete & 12 \\
\hline 2 & styrofoam & 4 \\
\hline 3 & concrete & 5 \\
\hline 4 & reinforced mortar & 1 \\
\hline 5 & styrofoam & 10 \\
\hline 6 & reinforced mortar & 0.2 \\
\hline 7 & glass fibre textile mesh & 0.1 \\
\hline 8 & reinforced mortar & 0.2 \\
\hline
\end{tabular}

\section{NUMERICAL MODELS}

Five numerical models have been proposed. The first three models $(\mathrm{A}, \mathrm{B}, \mathrm{C})$ relate to the wall before thermo-modernization and the two next $(\mathrm{D}, \mathrm{E})$ - the wall after insulation. Therefore in models A, B and C the layers listed in Fig. 2 and Table 1 as (1) - (3) have been considered, while in the cases of D and E models, the eight layers (1) - (8) (cf. Fig. 2, Table 1) have been taken into account.

In model A thickness of the whole wall was reduced to the thickness of load-bearing layer $(12 \mathrm{~cm})$. Stiffnesses of styrofoam and elevation layer have not been taken into account. However, additional mass from these parts of the wall has been included.

In model B thickness of the wall is the same as thickness of prefabricated panel $(21 \mathrm{~cm})$, but the equivalent (substitute) Young modulus and equivalent (substitute) Poisson's ratio were prepared with the consideration of mechanical properties of all of the layers. Equations (3.1) and (3.2) were applied for this purpose:

$$
\begin{gathered}
E_{\text {eqv }}=\frac{\sum_{i} E_{i} \cdot d_{i}}{\sum_{i} d_{i}} \\
v_{\text {eqv }}=\frac{\sum_{i} v_{i} \cdot d_{i}}{\sum_{i} d_{i}}
\end{gathered}
$$

where:

$E_{e q v}, v_{e q v}$ - equivalent Young modulus and Poisson's ratio for the whole model, $E_{i}, v_{i}$ - Young modulus and Poisson's ratio for particular, subsequent layers and $d_{i}-$ thickness of the layer. 
All actual layers with their actual Young modulus and Poisson's ratio were taken into account in the model C. So it is the most accurate model of prefabricated wall panel.

Model D was created in the same way as model B - all the eight layers were reduced to one layer with parameters obtained using Equations (3.1) and (3.2).

Model $\mathrm{E}$ is an analogous version to $\mathrm{C}$ model, but including all the eight layers.

In each of models three variants of additional mass from cooperating ceilings were also considered: I - no extra mass from ceilings, II - the mass of ceiling strips with a width of $1 \mathrm{~m}$, III - the mass of ceiling strips with a width of $2.7 \mathrm{~m}$.

Computations were carried out in Finite Element Method System Ansys [17] using 8-node multilayer structural shell element SHELL281 which is well-suited for both linear and nonlinear applications and dedicated to be used for modelling composite shells or sandwich constructions [17]. Specifying the thickness, material, orientation, and number of integration points through the thickness of the layers are available. This element uses the first-order shear-deformation theory and the default number of integration points for each layer is three [17]. Additionally, the results obtained with the application of element SHELL281 were compared with analogous ones originating from the calculations with using a bit less complex, reducing a numerical effort, only 4node multi-layer structural shell element SHELL181.

All materials of wall layers were modelled as isotropic and linear elastic. Their parameters are summarized in Table 2.

Table 2. Material parameters $[2,7,8]$

\begin{tabular}{|c|c|c|c|}
\hline Material & $\begin{array}{c}\text { Young modulus } \\
\boldsymbol{E}[\mathbf{G P a}]\end{array}$ & $\begin{array}{c}\text { Poisson's ratio } \\
\boldsymbol{v}[-]\end{array}$ & $\begin{array}{c}\text { Mass density } \\
\boldsymbol{\rho}\left[\mathbf{k g} / \mathbf{m}^{\mathbf{3}}\right]\end{array}$ \\
\hline concrete & 20 & 0.2 & 2500 \\
\hline styrofoam & 0.003 & 0.07 & 13 \\
\hline reinforced mortar & 20 & 0.2 & 2000 \\
\hline glass fibre textile mesh & 66 & 0.23 & 2550 \\
\hline
\end{tabular}

\section{RESUlts}

To illustrate the results obtained using the proposed various models, the first and the second natural horizontal vibration frequencies $\left(f_{1}, f_{2}\right)$ of the modelled building wall were compared. It was stated from the experimental full-scale measurements that the horizontal vibrations with the fundamental natural frequency are dominant in the cases of buildings with load bearing prefabricated walls. 
Sometimes the second mode of horizontal vibrations can occur $[5,13]$. As an example, natural horizontal vibration modes of model $\mathrm{C}$ are presented in Fig. 3.

a)

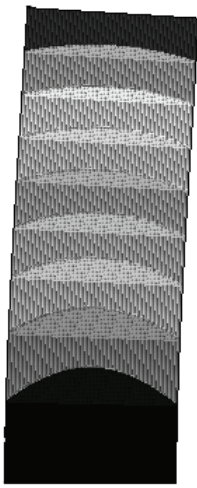

b)

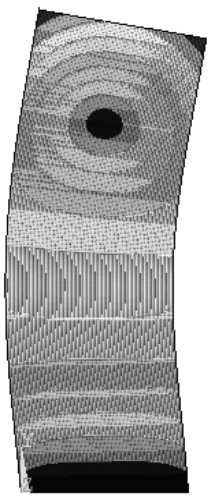

Fig. 3. Model $\mathrm{C}$ - natural horizontal vibration modes related to: a) $f_{1}$, b) $f_{2}$

In Fig. 4a the comparison of the influence of A, B, C load bearing wall modelling (without additional thermal insulation) on the first natural frequency of horizontal vibrations $f_{1}$ is shown. The similar relations in plots regarding the case of the second natural frequency of horizontal vibrations $f_{2}$ were obtained (Fig. $4 \mathrm{~b}$ ). It is visible that taking into account stiffness of all three layers results in an increase of values of the analysed vibration frequencies $f_{1}, f_{2}$. Additionally, the differences between the results obtained with using the simple model $\mathrm{B}$ and the multilayered model $\mathrm{C}$ are negligible for practical purposes. A similar observation concerns the D and E models of thermomodernized wall (Fig. 5).

a)

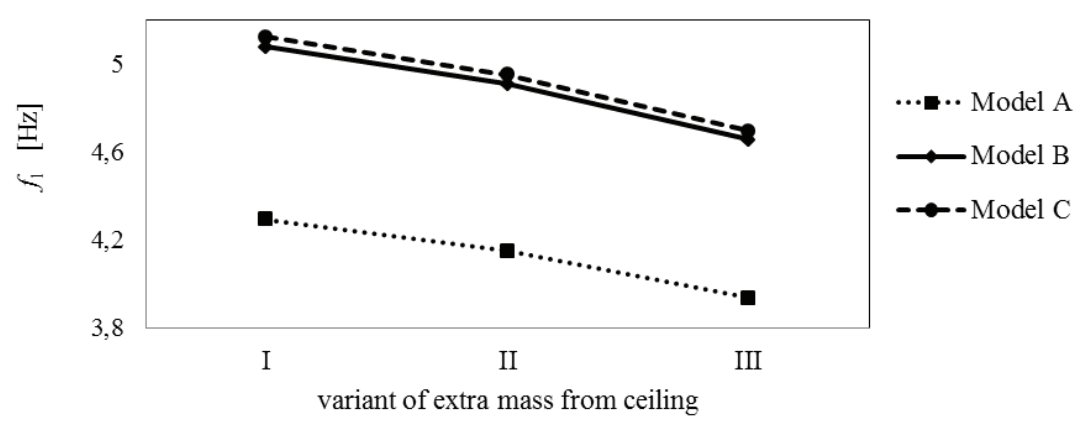


b)

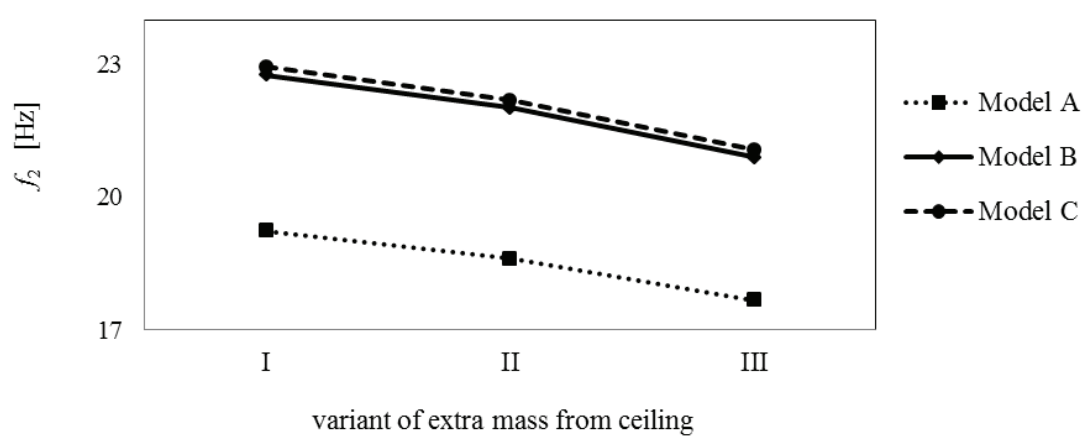

Fig. 4. Comparison of the influence of load bearing wall modelling on the natural frequencies of horizontal vibrations: a) $f_{1}$; b) $f_{2}$

Furthermore, looking at Fig. 5 it is visible that the thermo-modernization of building walls (mass and stiffness of thermal insulation layers addition) causes changes of the values of wall natural vibration frequencies.

a)

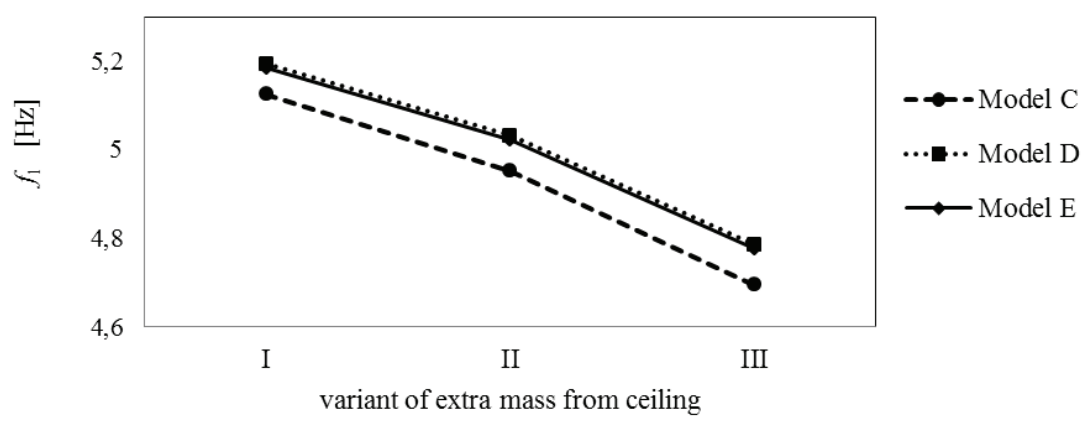

b)

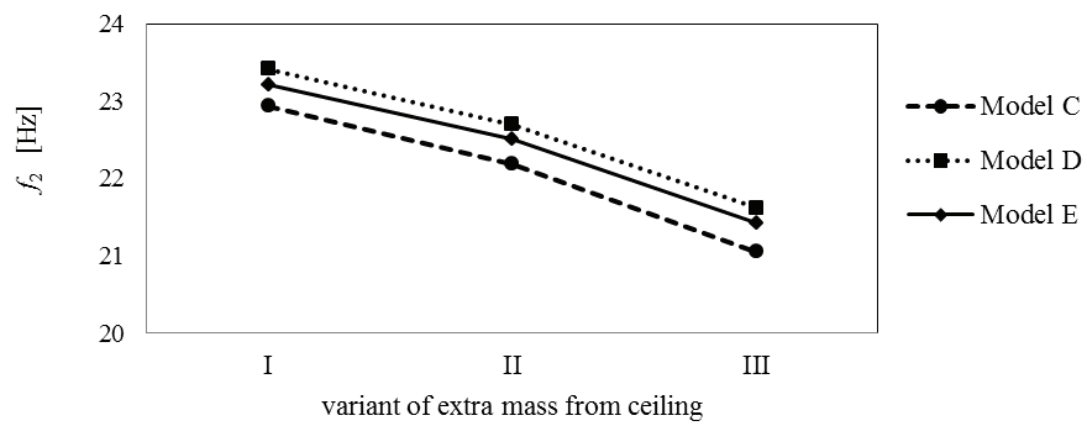


Fig. 5. Comparison of the values of natural frequencies $\left(f_{1}\right.$ as well as $\left.f_{2}\right)$ of wall horizontal vibrations for models of wall with and without thermo-modernization

As the example, in Fig. 6 the comparison of the values of natural frequencies $\left(f_{1}\right.$ as well as $\left.f_{2}\right)$ of wall horizontal vibrations obtained in the cases of applications of SHELL281 and SHELL181 elements for model E (multi-layer wall after thermo-modernization) is shown. It is visible that the values of $f_{1}$ frequencies are practically the same for models based on both of the elements, whereas the values of $f_{2}$ frequencies are a little different. Therefore the element SHELL281 can be advised for thermo-modernized wall modelling in the case of calculating of natural frequencies as the more precise. But it is worth remind that the values of frequencies obtained using the very simple model D (one-layer with the equivalent Young modulus and equivalent Poisson's ratio) are very close to values from model E with SHELL281 element (Fig. 5).

a)

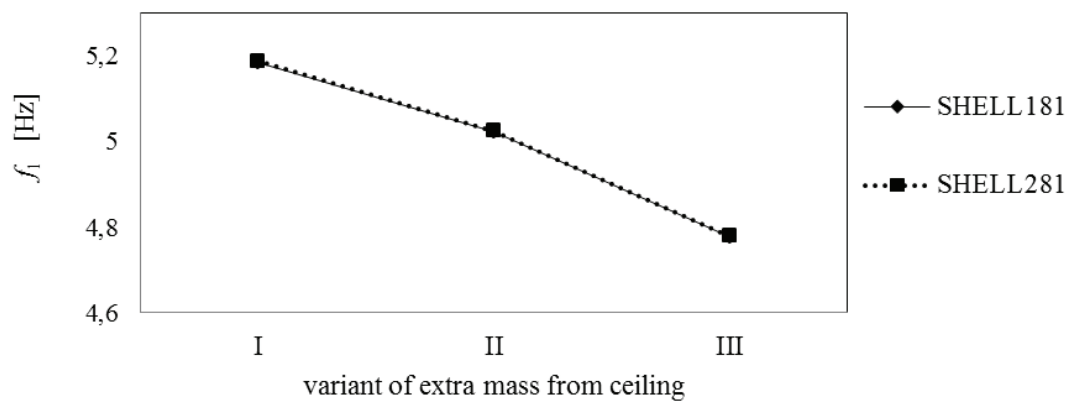

b)

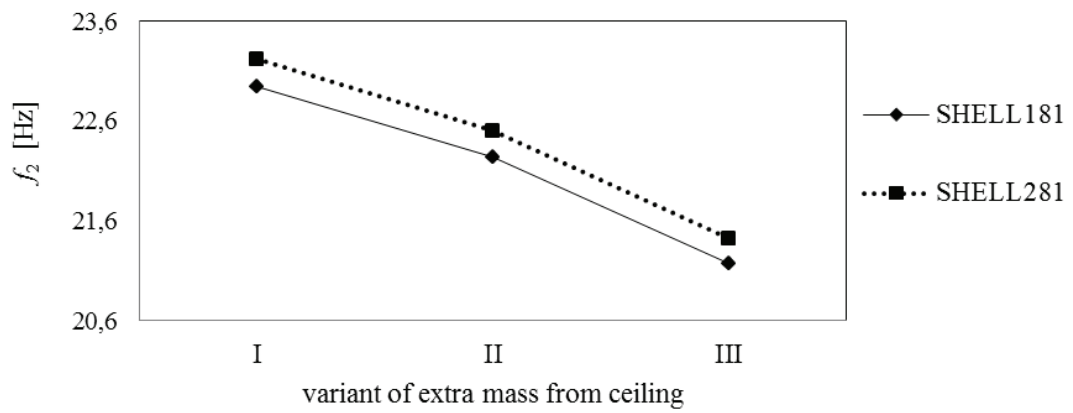

Fig. 6. Comparison of the values of natural frequencies $\left(f_{1}\right.$ as well as $\left.f_{2}\right)$ of wall horizontal vibrations obtained in the case of model $\mathrm{E}$

It also can be stated that the three default number of integration points for each layer of the element SHELL281 [17] is enough in the cases of all considered models. Introduction to the calculations 
more integration points (five, seven and nine) does not affect the values of natural frequencies of vibrations of the walls.

\section{CONCLUSIONS}

In the paper various approaches to the modelling of prefabricated load bearing walls before and after thermo-modernization have been presented.

The numerical results show that:

1. thermo-modernization can change values of natural horizontal vibration frequencies of prefabricated walls,

2. application of the simple model reducing multilayer panel to one layer panel with equivalent Young modulus and Poisson's ratio allows to receive results with good accuracy in the cases of all considered variants of additional mass from cooperating ceilings,

3. therefore the reduction of a numerical effort is possible, which can be especially prospective and important in the cases of models of such large structures as the whole apartment prefabricated buildings.

\section{REFERENCES}

[1] H. G. Allen., "Analysis and design of structural sandwich panels”, Pergamon Press 1969.

[2] R. J. Bathurst, S. Zarnani, A. Gaskinszósty, "Shaking table testing of geofoam seismic buffers", Soil Dynamics and Earthquake Engineering, Elsevier, Vol. 27, No. 4, pp. 324-332, 2007.

[3] B. Blache, J. L. Salagnac, "Modernizacja budynków z płyt prefabrykowanych: doświadczenia francuskie", Materiały konferencyjne, Mrągowo, 3-5 listopada 1999 r., Instytut Techniki Budowlanej, pp. 43-74, Warszawa 1999.

[4] C. Cardoso, S. Jalali, "Thermal performance characterization of na modular system for facade", Key Engineering Materials, Vol. 634, pp. 62-71, 2015.

[5] R. Ciesielski, K. Kuźniar, E. Maciąg, T. Tatara, "Empirical formulae for fundamental natural periods of buildings with load bearing walls", Archives of Civil Engineering, Vol. 38, No. 4, pp. 291-299, 1992.

[6] J. M. Davies (Editor), "Lightweight sandwich constructions", Blackwell Science Ltd. 2001.

[7] Z. Dzierżewicz, W. Starosolski, "Precast concrete panel building systems in Poland in the years 1970-1985", Wolters Kluwer Polska, Warsaw, Poland, 2010 (in Polish).

[8] D. Hartman, M. E Greenwood., D. M. Miller, "High Strength Glass Fibres", AGY Technical Paper, USA, 2006.

[9] H. D. Hegner, “Wielkie osiedla i budynki wielkopłytowe - wizja przyszłości!?”, Materiały konferencyjne, Mrągowo, 3-5 listopada 1999 r., Instytut Techniki Budowlanej, pp. 73-106, Warszawa 1999.

[10]ITB instruction, "External thermal insulation composite systems", Building Research Institute, Warsaw, Poland, 2002 (in Polish).

[11]K. Kuźniar, E. Maciąg, T. Tatara, "Prediction of Building Foundation Response Spectra from Mining-Induced Vibrations using Neural Networks", Mining \& Environment, Vol. 4, No. 4, pp. 50-64, 2010.

[12]M. Liping, W. Ying, J. Quan, Z. Chunzhi, Z. Ping, "Evaluation and Selection Research on External Wall Insulation Materials Based on Green Building Energy Conservation”, Materials Science Forum, Vol. 814, pp $524-532,2015$. 
[13]E. Maciąg, K. Kuźniar, T. Tatara, "Response Spectra of Ground Motions and Building Foundation Vibrations Excited by Rockbursts in the LGC Region", Earthquake Spectra, Vol. 32, No. 3, pp. 1769-1791, 2016.

[14]P. Nowak, M. Skłodkowski, "Multicriteria Analysis of Selected Building Thermal Insulation Solutions", Archives of Civil Engineering, Vol. 62, No. 3, pp. 137-148.

[15]A.M. Papadopoulos, E. Giama. "Environmental performance evaluation of thermal insulation materials and its impact on the building", Building and Environment, Vol. 42, pp. 2178-2187, 2007.

[16]G. Woltman, D. Tomlinson, A. Fam, "Investigation of Various GFRP Shear Connectors for Insulated Precast Concrete Sandwich Wall Panels”, Journal of Composites for Construction”, Vol. 17, No. 5, pp. 711-721, 2013.

[17]Release 11.0 Documentation for Ansys, 2007.

[18]D. Zenkert , “An Introduction to Sandwich Construction”, Eastbourne, EMAS 1995

\section{LIST OF FIGURES AND TABLES:}

Fig. 1. Typical high-rise prefabricated apartment building

Rys. 1. Typowy wysoki mieszkalny budynek prefabrykowany

Fig. 2. Layers of the analysed wall

Rys. 2. Układ warstw analizowanej ściany

Fig. 3. Model $\mathrm{C}$ - natural horizontal vibration modes related to: a) $f_{1}$; b) $f_{2}$

Rys. 3. Model $\mathrm{C}$ - postacie poziomych drgań własnych odpowiadające: a) $f_{1}$; b) $f_{2}$

Fig. 4. Comparison of the influence of load bearing wall modelling on the natural frequencies of horizontal vibrations: a) $f_{1}$; b) $f_{2}$

Rys. 4. Porównanie wpływu modelu numerycznego ściany nośnej na częstotliwości poziomych drgań własnych: a) $f_{1}$; b) $f_{2}$

Fig. 5. Comparison of the values of natural frequencies $\left(f_{1}\right.$ as well as $\left.f_{2}\right)$ of wall horizontal vibrations for models of wall with and without thermo-modernization

Rys. 5. Porównanie wartości częstotliwości poziomych drgań własnych $\left(f_{1}\right.$ oraz $\left.f_{2}\right)$ ściany w przypadku modeli ściany po i przed termomodernizacją

Fig. 6. Comparison of the values of natural frequencies $\left(f_{1}\right.$ as well as $\left.f_{2}\right)$ of wall horizontal vibrations obtained in the case of model $\mathrm{E}$

Rys. 6. Porównanie wartości częstotliwości poziomych drgań własnych $\left(f_{1}\right.$ oraz $\left.f_{2}\right)$ ściany w przypadku modelu E

Tab. 1. Wall layers and their thickness

Tab. 1. Układ i grubości warstw ściany

Tab. 2. Material parameters $[2,7,8]$

Tab. 2. Parametry materiałowe $[2,7,8]$ 


\section{MODELE NUMERYCZNE DO OCENY CZESTOTLIWOŚCI DRGAŃ WLASNYCH ŚCIAN BUDYNKÓW PO TERMOMODERNIZACJI}

Slowa kluczowe: modele numeryczne, termomodernizacja ścian, częstotliwości drgań własnych, metoda elementów skończonych

\section{STRESZCZENIE:}

Klasa typowych budynków prefabrykowanych jest stosunkowo liczna wśród budynków mieszkalnych w Polsce. Budynki te powstawały w latach pięćdziesiątych, sześćdziesiątych i siedemdziesiątych dwudziestego wieku. Obecnie, na skutek nowych przepisów dotyczących ochrony środowiska i właściwości cieplnych obiektów budowlanych oraz oczekiwań współczesnych mieszkańców, budynki te są modernizowane. Zasadnicze zmiany dotyczą izolacyjności cieplnej ścian.

Tego typu modernizacje są szeroko stosowane, np. we Francji już od lat siedemdziesiątych ubiegłego wieku. We wschodnich Niemczech po upadku Muru Berlińskiego zmiany te dotyczą nie tylko termomodernizacji budynków, ale też modyfikacji ich wyglądu. Również w Polsce, z wykorzystaniem funduszy europejskich, wiele budynków prefabrykowanych (mieszkalnych i użyteczności publicznej) jest ocieplanych.

Tego typu modyfikacje zwiększają masę budynku oraz zmieniają sztywność. Zmianie mogą zatem ulec właściwości dynamiczne obiektów, wśród nich - częstotliwości drgań własnych, których wartości wykorzystywane są w analizie obiektów budowlanych poddawanych oddziaływaniom sejsmicznym lub parasejsmicznym.

Najpopularniejsze technologie ocieplania ścian skutkują zwiększeniem grubości ściany w wyniku wprowadzenia dodatkowych warstw styropianu, wełny mineralnej, zbrojonej zaprawy, siatki z włókna szklanego. W literaturze do analizy takich płyt sandwiczowych proponowane są różne modele numeryczne.

Duża liczba opublikowanych artykułów dotyczy badań wpływu rozwiązań konstrukcji ściany z izolacją cieplną na zmniejszenie zużycia energii. Natomiast problemy analizy dynamicznej budynków po termomodernizacji są bardzo rzadko podejmowane.

W niniejszej pracy pokazano różne podejścia do modelowania prefabrykowanych ścian nośnych przed i po termomodernizacji. Wykorzystując metodę elementów skończonych rozważono proste, jednowarstwowe modele o zastępczej sztywności oraz modele wielowarstwowe. Porównywano częstotliwości ich poziomych drgań własnych.

Rozważono wysoką, typową prefabrykowaną ścianę nośną systemu budownictwa prefabrykowanego WWP - 10.8m szerokości i $29.7 \mathrm{~m}$ (11 kondygnacji x $2.7 \mathrm{~m}$ ) wysokości. Każda płyta prefabrykowana składa się z trzech warstw: nośnej, izolacji cieplnej i elewacyjnej. Dodatkowe warstwy wynikające z termomodernizacji tworzą: zbrojona zaprawa, styropian i siatka z włókien szklanych.

Zaproponowano pięć modeli numerycznych. Pierwsze trzy modele (A, B, C) dotyczą ściany przed termomodernizacją, kolejne dwa (D, E) - ściany po ociepleniu. Zatem w modelach A, B i C uwzględniono trzy warstwy, a w przypadku modeli D i E - osiem warstw.

W modelu A grubość całej ściany została zredukowana do grubości warstwy nośnej $(12 \mathrm{~cm})$. Sztywności styropianu i warstwy elewacyjnej nie zostały uwzględnione, ale ich masa została dodana w modelu.

W modelu B grubość modelu ściany jest taka sama jak grubość płyty prefabrykowanej $(21 \mathrm{~cm})$. W przypadku tego modelu zaproponowano zastępcze wartości modułu Younga i współczynnika Poissona, uwzględniające parametry poszczególnych warstw. 
Wszystkie rzeczywiste warstwy oraz ich rzeczywiste moduły Younga i współczynniki Poissona zostały wprowadzone w modelu C. Jest to zatem najbardziej dokładny model ściany prefabrykowanej.

Model D utworzono w taki sam sposób jak model B - wszystkie osiem warstw zostało zredukowanych do jednej warstwy o zastępczych parametrach.

Model E jest modelem analogicznym do modelu $\mathrm{C}$, ale zawierającym osiem warstw.

W każdym rozpatrywanym modelu rozważono trzy warianty dodatkowej masy pochodzącej od stropów współpracujących ze ścianą: I - pominięcie masy stropów, II - masa stropów z pasm o szerokości 1m, III - masa stropów z pasm o szerokości $2.7 \mathrm{~m}$.

Obliczenia przeprowadzono w systemie metody elementów skończonych Ansys z wykorzystaniem 8-węzłowego elementu SHELL281. Element ten jest szczególnie przydatny w modelowaniu struktur kompozytowych oraz sandwichowych. W danych wejściowych możliwe jest określanie grubości, parametrów materiałowych, orientacji i liczby punktów całkowania po grubości poszczególnych warstw. Dodatkowo, wyniki uzyskane z użyciem elementu SHELL281 porównano $\mathrm{z}$ analogicznymi rezultatami pochodzącymi $\mathrm{z}$ obliczeń za pomocą nieco mniej złożonych, redukujących wysiłek numeryczny, tylko 4-węzłowych elementów SHELL181. Materiały wszystkich warstw modelowano jako izotropowe liniowo-sprężyste.

W celu zilustrowania wyników otrzymanych za pomocą różnych modeli, porównywano pierwszą $\left(f_{1}\right)$ i drugą częstotliwość $\left(f_{2}\right)$ poziomych drgań własnych rozważanej ściany budynku. Z badań doświadczalnych na obiektach rzeczywistych wynika, że w przypadku ścianowych budynków prefabrykowanych, poziome drgania z podstawową częstotliwością drgań są dominujące. Czasem mogą pojawić się drgania z drugą postacią drgań.

W przypadku modelowania ściany bez dodatkowej warstwy izolacji cieplnej (modele A, B, C) stwierdzono, że uwzględnienie w modelu sztywności wszystkich trzech warstw powoduje wzrost wartości częstotliwości $f_{1}$ i $f_{2}$. Poza tym, różnice między wartościami otrzymanymi z użyciem prostego modelu $\mathrm{B}$ i wielowarstwowego modelu $\mathrm{C}$ są zaniedbywalnie małe w praktycznych zastosowaniach. Podobne spostrzeżenie dotyczy modeli D i E ściany po termomodernizacji. Zatem redukcja wysiłku numerycznego jest możliwa, co może być szczególnie ważne i perspektywiczne w przypadku tak dużych konstrukcji, jakimi są całe prefabrykowane budynki mieszkalne.

Ponadto wyniki przeprowadzonych obliczeń wskazują, że termomodernizacja ścian budynku (masa i sztywność dodanych warstw izolacji cieplnej) może zmienić wartości częstotliwości drgań własnych ściany.

Wartości częstotliwości drgań własnych $f_{2}$ ścian obliczone z użyciem elementów SHELL281 i SHELL181 mogą się nieco różnić, podczas gdy obliczane wartości $f_{1}$ są praktycznie takie same. Zatem w przypadku obliczeń częstotliwości drgań własnych wielowarstwowej ściany po termomodernizacji można byłoby rekomendować element SHELL281, jako bardziej precyzyjny niż element SHELL181. Zwiększenie liczby punktów całkowania dla każdej warstwy elementu SHELL281 z trzech do pięciu, siedmiu i dziewięciu nie wpływa na wyliczane wartości częstotliwości drgań. 